\title{
Active Tectonic Signs of Taftan Mountain (South Eastern of Iran)
}

\author{
Mohsen Jami*, Ali Solgi, Mohsen Pourkermani, Ali Asghar Moridi Farimani \\ Department of Geology, Science and Research Branch, Islamic Azad University, Tehran, Iran \\ Email: " Mohsenjami84@yahoo.com
}

Received 5 June 2015; accepted 22 September 2015; published 25 September 2015

Copyright (C) 2015 by authors and Scientific Research Publishing Inc.

This work is licensed under the Creative Commons Attribution International License (CC BY). http://creativecommons.org/licenses/by/4.0/

(c) (i) Open Access

\begin{abstract}
This area, $12585.84 \mathrm{Km}^{2}$, is located around Taftan Mountain in the east of Iran. It lies between latitudes $27^{\circ} 51^{\prime}$ and $29^{\circ} 30^{\prime} \mathrm{N}$, and longitudes $60^{\circ} 19^{\prime}$ and $61^{\circ} 43^{\prime} \mathrm{E}$. It has been studied on quantitative and qualitative morphometric and other active tectonic indices including symmetry of drainage basin (Asymmetry Factor), symmetry of latitudinal topography and sinuosity of main front. It is founded that relative active tectonic levels have been categorized in three groups: high, low and middle. Finally, all indices have been integrated with desert relations. Then the relative active tectonic level in area of 3-B is high; it is middle in the areas and sub-areas 1 of 1-B, 1-C, 1-D, 1-E, 3-A, 3-B, 4-A, 4-C, 5-A, 5-B, 9-A, 9-B and 9-C and it is low in sub-areas of 1-C and 9-A. The relative active tectonic levels in the east and south eastern areas where Mirjaveh and Khash cities are located are higher than other areas. Tectonic actions of the areas and sub-areas have been matched with structural elements.
\end{abstract}

\section{Keywords}

Taftan Mountain, Tectonic, Morphometric, Khash

\section{Introduction}

Taftan has been located in southeastern Iran (Figure 1); it is an active area tectonically but it seems that it has been affected on different areas differently. According to it and being near to northern area of Saravan Fault, it is important to evaluate the relative active tectonic level of this area and to compare their relative active tectonic levels. It seems that young volcano and active tectonics have played an important role to morphologic characteristics of the area. Morphometric indices have been used to study on tectonic actions. In studying on relative active tectonic levels, morphometric indices are very beneficial (10), (7), (12), (15), (13). Morphometric studies

*Corresponding author. 


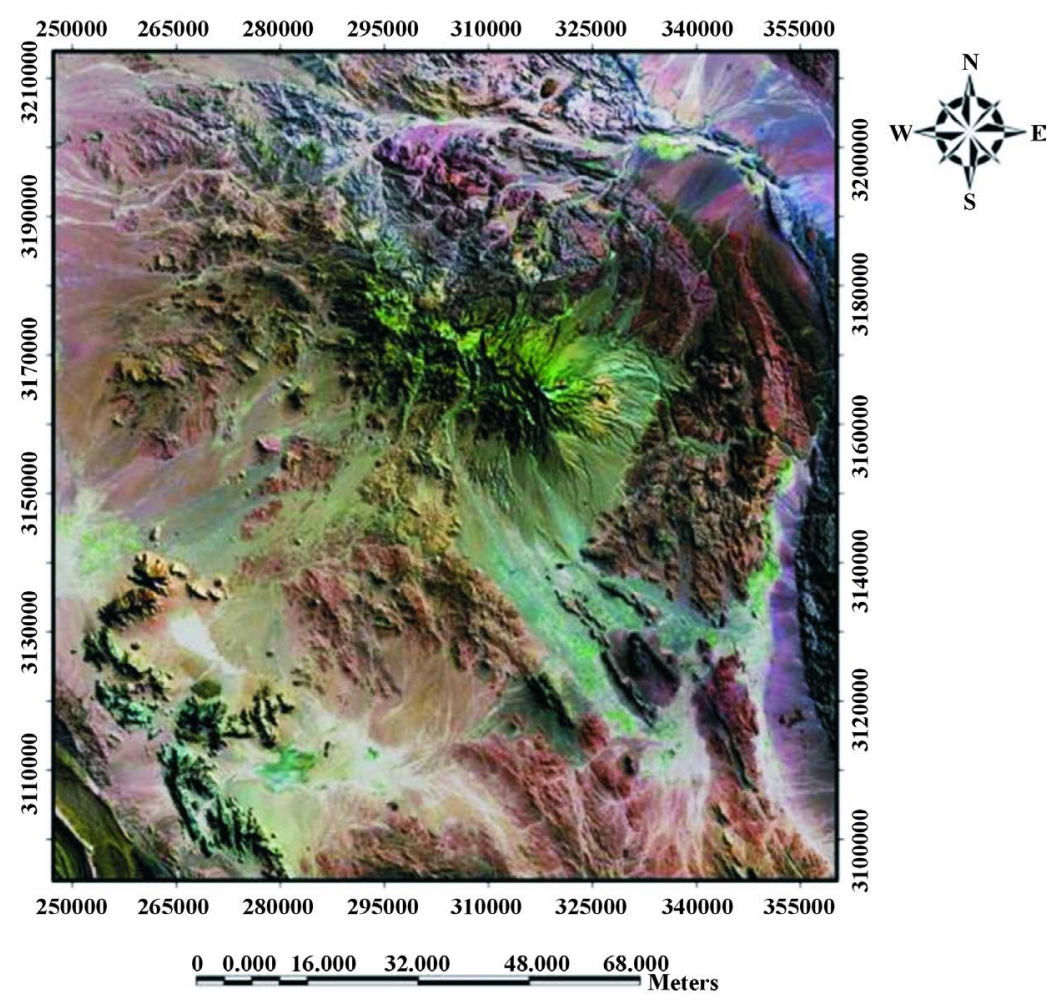

Figure 1. Satelite pictures and position of the area.

include Asymmetry of drainage basin (Af), Longitudinal Topography (T), and Sinuosity Main Front (Smf). In this paper, active tectonics of basin and categorization of relative tectonic actions in the area have been studied.

According to theory [1], Iran Map can be divided into Sedimentary-Structural Zones, Zagros Trust Zone, Sanandaj-Sirjan Zone, Oroomiyeh Dokhtar Magma Arc, Central Area of Iran, Flysch Zone of East of Iran, Loot Block, Alborz Zone, Kopeh dagh and Makran (Figure 2). Regarding Taftan Volcano which is suited in Flysch Sedimentary-Structural Zone of the east, specifications and structural evolution have been considered in this paper.

\section{Flysch Basin East of Iran}

In the eastern terminal of the middle, between two Nehbandan Fault (in the west) and Harirrood Fault (in the east), in the range of an area $800 \mathrm{~km}$ long and $200 \mathrm{~km}$ wide, stacked such thick deposits flysch where contain Ophiolite host rock belonged to oceanic crusts. This area where passed its structural evolution fromoceanic to continental crusts is one of derivations of young Tethys. It is also called Mountains of east Iran [2], Flysch Zone [3], Nehbandan-Khash Zone [4], Zabol-Balouch Zone [4], Iranshahr-Birjand Area [5], Sistan suture Zone [6]. Although eastern and western boundaries are clear with Nehbandan and Harirrood Faults but northern and southern borders are not so clear. North terminal zone has been branched as a result of strike-slip fault and trended toward the west and northern west and continued to south of Birjand and Basiran. In the southern border, north-southern progress has been also trended toward southern east and continued to Pakistan. Because of this structural pattern, the east Flysch Basin is a Fault Basin Transformation that Nehbandan and Harirrood Faults and Block Rotation of Loot and Hirmnad have played important role to form.

\section{Tectonics}

Structural pattern of Flysch Basin east of Iran where placed on the two continental plates, the Loot and Hirmand, and especially master land construction is very complex and represent an orogeny in continent. It is that the thrusts have played important role as folding of the stones is outcome of the thrust. In the middle part of the basin, strike-slip fault trends toward north-south approximately and they are steep to the east. But in the north and southern terminals, the structures have been changed as a result from rotation of Loot Block and Helmand 


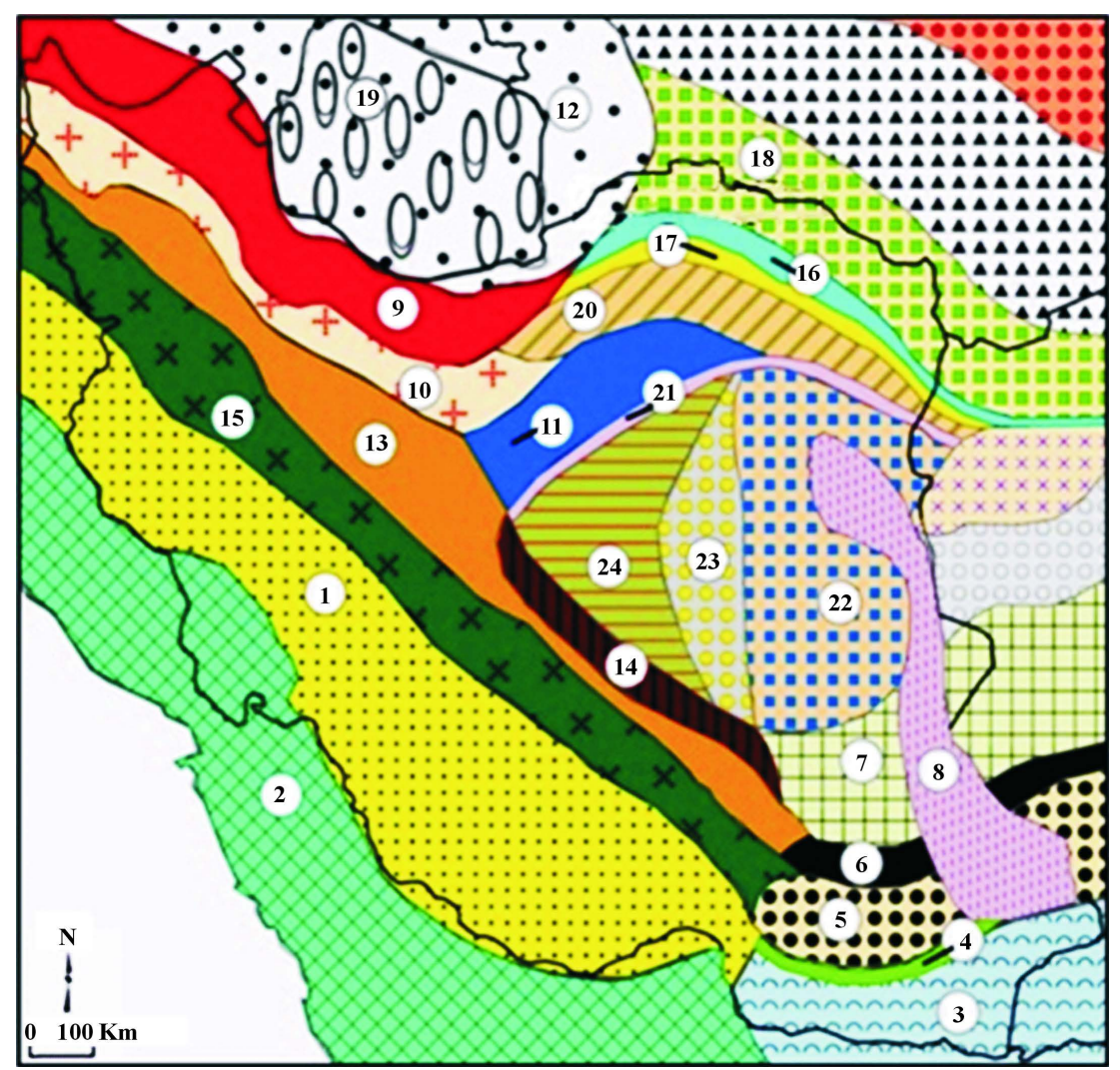

Figure 2. Physiographic-tectonic zoning map of Iran's sedimentary basins Iran, modified from [7]. Numbers in this figure are, 1: Zagros-East Taurus hinterland, 2: Persian Gulf-Mesopotamian foreland. basin, 3: Makran accretionary prism, 4: Bashagard Mountains, 5: Jazmorian-Mashkel fore arcbasin, 6: Shahsavaran-Soltan magmatic arc, 7: South Lut-South Helmand back arc basin, 8: East Iran Mountain belt, 9: West-Central Alborz and Lesser Caucasus hinterland, 10: Great Kavir-Northen Urmieh lake foreland basin, 11: South Great Kavirfold and thrust belt, 12: South Caspian-Black sea foreland basin, 13: Urmieh-Dokhtar Magmatic Arc, 14: NaienKerman retro arc foreland basin, 15: Sanandaj-Sirjanoverthrust belts, 16: East Alborz or Binalod hinterland, 17: Torbat-e jam-Neyshabour retro arc foreland basin, 18: Kope Dagh hinterland, 19: South Caspian remnant basin, 20: Maiamay-Taibad Inverted back arc basin, 21: Khaf-Kavir Plain Magmatic Arc, 22: Lut Plain-Gonabad back arc basin, 23: Tabas hinterland, 24: Yazd-Khour Piggy back basin.

Bloch to the right and the nature of the faults is mainly from thrust of overlaps. Although in the major part of Iran, moving to the north and northeast of Arabian Plate-Africa is involved, but in flysch basin east of Iran moving to the north and northwest of Indian Plate and its consequences are effective, in other words, the main structures of the area should be found from forming Indian Ocean.

\section{Earthquake}

From view of earthquake fertility, middle part of Flysch Basin East of Iran around Zahedan was entirely peaceful in the past century but the northern and southern parts had caused to be earthquake. In the area of Nehbandan, there is Quake Type of Shallow $(0-35 \mathrm{~km})$ in the average size of 3.5 - 6 Richter. In the south particularly around Taftan, there are earthquakes types of deep and semi-deep in the size of 3.5 - 7 Richter. Some parts of focuses of earthquake are accordance with zones intersected with Loot Block in the west [8].

\section{Discussion}

Tectonics has studied on tectonic processes that related to the human communities. The tectonic processes include 
earthquake, landslide, uplifts, subsidence, tilting, active folds, active fault, fans, rivers, morphometric, etc. In this literature, morphometric and come indices have been used to evaluate the relative active tectonic level. Qualitative and quantitative indices have been considered to study on morphometric. They provide much information about tectonic position of the area. In the other words, morphs are as result from rate of tectonic actions. These findings plus other information such as uplifts can be providing tectonic action class. They indicate the relative active tectonic level (3). In this area, asymmetry of drainage basin, symmetry of latitudinal topography and sinuosity of main front have been computed. This area has been divided to 9 basins. They have been separated on the basis of topographic maps 1:50,000, Landsat images 30 and $15 \mathrm{~m}$, IRS (5.5 m), SRTM (30 m), Zahedan Geology Maps 1:250,000, Khash 1:250,000, Iranshahr1:250,000 and nareno 1:250,000. Their positions have been drawn on the basis of the main river and some factors such as topographic slop (Figure 3) illustrates position of the area and separation of main rivers and branches.

\subsection{Asymmetry of Drainage Basin (Asymmetry Factor)}

Geometry of river network has been describes qualitatively and quantitatively, a place where drainage is developed with an active tectonic and the net often suggests clear pattern and geometry. This method can be used for big areas [9] [10]. The Equation (1) can be used to find tectonic tilting in the drainage scale or big areas.

(1)—Drainage Basin Asymmetry (Af): Af $=(\mathrm{Ar} / \mathrm{At}) 100$.

When a river network is formed and its flow is fixed in one, AF should be about $50 \%$. The quantities that are less or more $50 \%$ indicate tilting. Af of morphometric indices is the best method for the areas where stone type is equal. Consequently, if Af is more than $50 \%$, it indicates that the mentioned area is tilting to the left [11]. Af

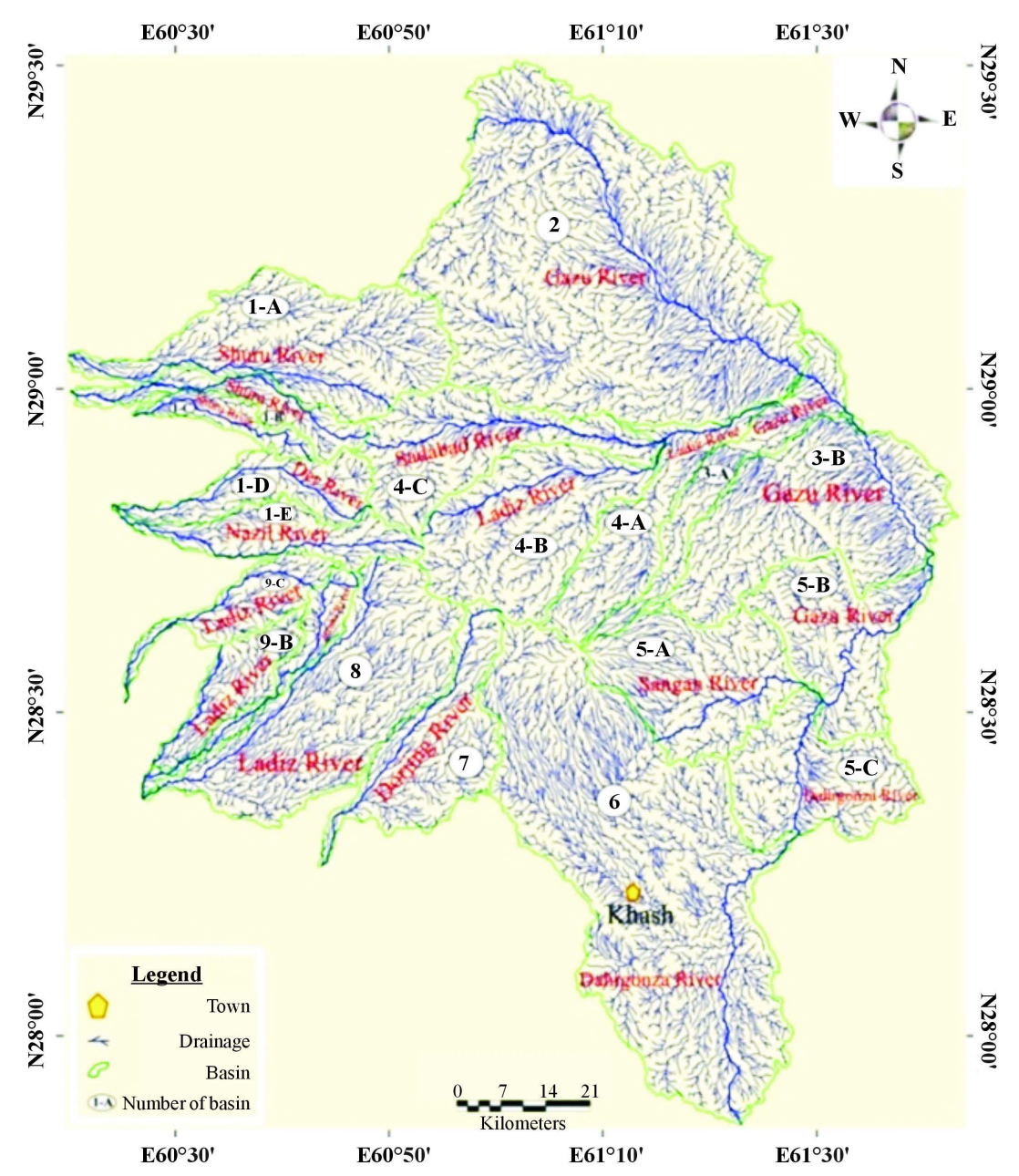

Figure 3. Position of the area and separation of main rivers and branches. 
has been evaluated for 20 basins and sub-basins in this area (Table 1). Except sub-basins 1-C, 1-D, 1-E, 4-C, the basins and sub-basins of this are progressed from south to north and vice versa. Af $<50$ is tilting to the west and Af $>50$ is tilting to the east. Symmetry of drainage basin has been evaluated by symmetry of latitudinal topography that indicates there is tilting in the most parts. As the basins and sub-basins 1-A (85.41), 1-C (56.85), 1-D (49.06), 1-E (72.90), 4-A (92.2), 4-B (78.84), 4-C (61.91), 5-C (53.97), 7 (17.10), 9 (9.70), 9-A (48.49), 9-B (7.78), 9-C (33.82) are tilting to the west and 1-B (38.64), 2 (68.68), 3-A (82.76), 3B (85.31), 5-A (22.53), 5-B (30.32) and 6 (12.61) are tilting to the east.

The sub-basin 1-D (49.06) is the most symmetrical case and 1-A, 1-E, 3-A, 3-B, 4-A and 4-B are tilting very much because of folding and moving as 4-A (92.02) is the most of all that is as a result from many minor faults related to the sub-basin. 9-B is the least of all and its direction is N-SW (Figure 4 \& Figure 5).

\subsection{Symmetry of Latitudinal Topography}

The Equation (2) has been used to evaluate asymmetry of basin.

(2) - Symmetry of latitudinal Topography (T): T = Da/Dd.

For a basin in complete symmetry $(T=0)$, asymmetry increases at a distance from middle line of the basin, then $\mathrm{T}$ also increases and comes near to amount of flow channel. Supposing that slop of bedrock has affected on moving flow channel insignificantly. Then $\mathrm{T}$ of a vector will be 0 and 1 . The values of $\mathrm{T}$ are comparable with different parts of valley and it indicates preferred moving of flow is vertical on drainage basin axis.

$\mathrm{T}$ can be computed similar to AF nearly but it can't evaluate direction of tilting directly as AF is a method that can evaluate amount and speed of tilting [11]. In this area, T or Symmetry of Latitudinal Topography is evaluated for 9 basins and 20 sub-basins (Table 2).

For a basin $\mathrm{T}=0$, If asymmetry increases, $\mathrm{T}$ will be increased and come near to one. Symmetry of drainage

Table 1. Af for the basins of the area.

\begin{tabular}{|c|c|c|c|c|c|}
\hline Basin & $A_{r}(s q \mathbf{k m})$ & $A_{t}(s q \mathbf{k m})$ & Af & Tilting Part & Flow Direction \\
\hline 1-A & 669.06 & 783.32 & 85.41 & west & SE-NW \\
\hline 1-B & 80.146 & 207.41 & 38.64 & east & SE-NW \\
\hline $1-C$ & 68.162 & 119.90 & 56.85 & west & SE-W \\
\hline 1-D & 132.12 & 269.29 & 49.06 & west & E-SW \\
\hline 1-E & 208.61 & 286.17 & 72.90 & west & SE-W \\
\hline 2 & $1,694.80$ & 2467.80 & 68.68 & east & NW-SE \\
\hline 3-A & 264.70 & 319.84 & 82.76 & east & NW-SE \\
\hline 3-B & 752.06 & 881.51 & 85.31 & east & NW-SE \\
\hline 4-A & 354.77 & 385.53 & 92.02 & west & SW-NE \\
\hline 4-B & 525.35 & 666.38 & 78.84 & west & SW-N \\
\hline $4-\mathrm{C}$ & 320.90 & 518.34 & 61.91 & west & W-NE \\
\hline 5-A & 130.00 & 576.94 & 22.53 & east & SW-NE \\
\hline 5-B & 149.16 & 492.01 & 30.32 & east & SW-NW \\
\hline $5-\mathrm{C}$ & 268.29 & 497.09 & 53.97 & west & S-NE \\
\hline 6 & 270.78 & 2146.70 & 12.61 & east & S-NE \\
\hline 7 & 81.455 & 476.38 & 17.10 & west & NE-S \\
\hline 8 & 87.145 & 898.36 & 9.70 & west & NE-SW \\
\hline 9-A & 75.488 & 155.69 & 48.49 & west & NW-S \\
\hline 9-B & 16.787 & 215.90 & 7.78 & west & N-SW \\
\hline 9-C & 74.75 & 220.99 & 33.82 & west & NE-S \\
\hline
\end{tabular}




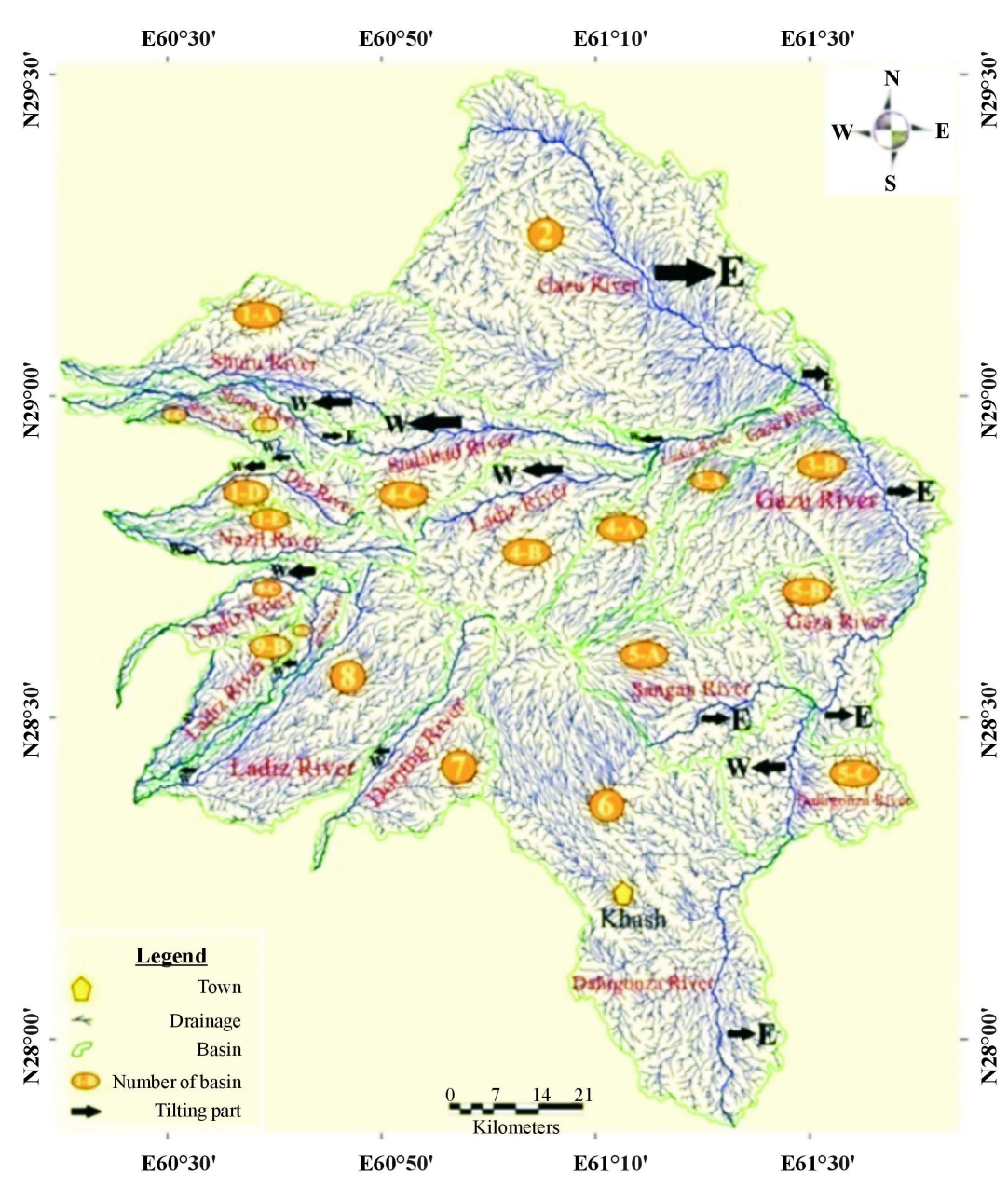

Figure 4. Positions of the basins and tilting areas based on Af.

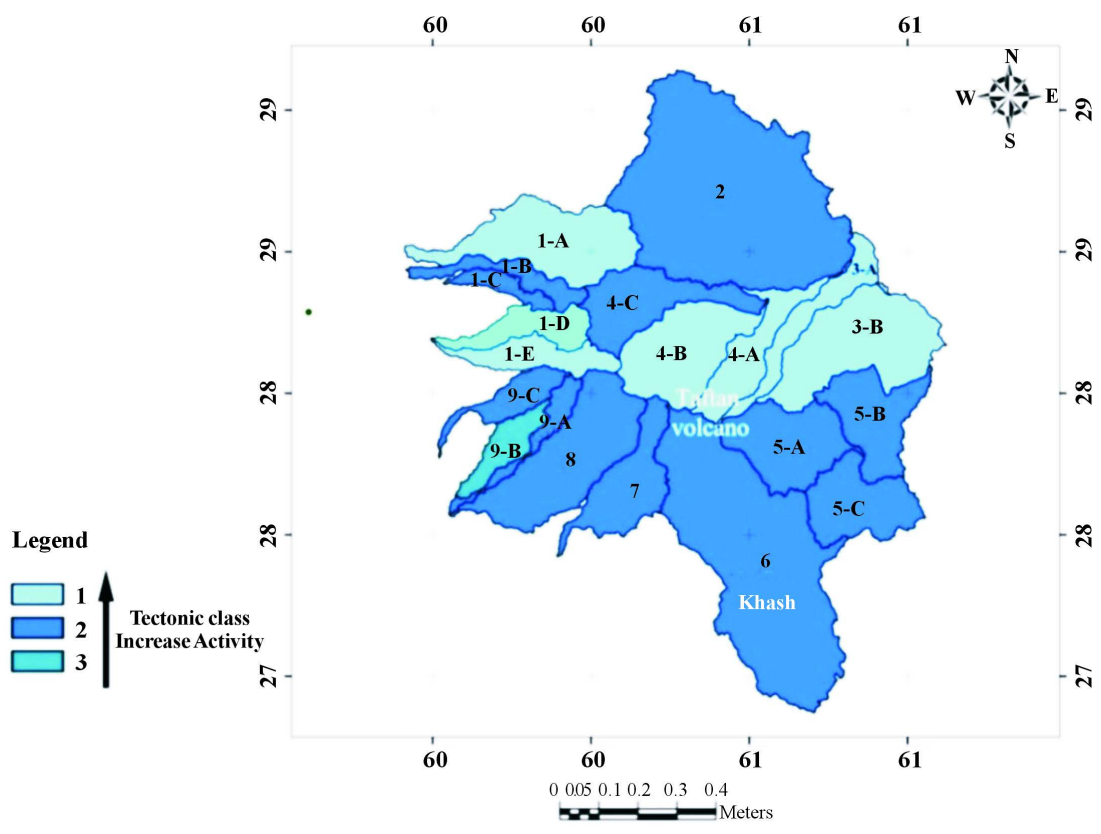

Figure 5. Positions of the basins and categorizing to three groups based on Af. 
Table 2. The values of $\mathrm{T}$ for the basins.

\begin{tabular}{|c|c|c|c|c|}
\hline Basin & Da (m) & Dd (m) & $\mathrm{T}(\mathrm{m})$ & $\mathrm{T}_{\text {ave }}(\mathrm{m})$ \\
\hline 1-A & 816 & 1245 & $\mathrm{~T}_{1}=0.66$ & \multirow{2}{*}{$\mathrm{T}_{1.2}=0.59$} \\
\hline 1-A & 833 & 1645 & $\mathrm{~T}_{2}=0.51$ & \\
\hline 1-B & 939 & 2331 & $\mathrm{~T}_{1}=0.40$ & \multirow{2}{*}{$\mathrm{T}_{1.2}=0.34$} \\
\hline 1-B & 838 & 3003 & $\mathrm{~T}_{2}=0.28$ & \\
\hline $1-C$ & 917 & 3086 & $\mathrm{~T}_{1}=0.30$ & \multirow{2}{*}{$\mathrm{T}_{1.2}=0.25$} \\
\hline $1-C$ & 838 & 4368 & $\mathrm{~T}_{2}=0.19$ & \\
\hline 1-D & 2859 & 3875 & $\mathrm{~T}_{1}=0.74$ & \multirow{2}{*}{$\mathrm{T}_{1.2}=0.67$} \\
\hline 1-D & 2701 & 4498 & $\mathrm{~T}_{2}=0.60$ & \\
\hline 1-E & 1186 & 2259 & $\mathrm{~T}_{1}=0.53$ & \multirow{2}{*}{$\mathrm{T}_{1.2}=0.47$} \\
\hline 1-E & 794 & 1997 & $\mathrm{~T}_{2}=0.40$ & \\
\hline 2 & 4575 & 7409 & $\mathrm{~T}_{1}=0.62$ & \multirow{2}{*}{$\mathrm{T}_{1.2}=0.67$} \\
\hline 2 & 4795 & 6766 & $\mathrm{~T}_{2}=0.71$ & \\
\hline 3-A & 1369 & 6234 & $\mathrm{~T}_{1}=0.22$ & \multirow{2}{*}{$\mathrm{T}_{1.2}=0.38$} \\
\hline 3-A & 1308 & 2464 & $\mathrm{~T}_{2}=0.53$ & \\
\hline 3-B & 2236 & 5395 & $\mathrm{~T}_{1}=0.41$ & \multirow{2}{*}{$\mathrm{T}_{1.2}=0.37$} \\
\hline 3-B & 2264 & 6877 & $\mathrm{~T}_{2}=0.33$ & \\
\hline 4-A & 668 & 883 & $\mathrm{~T}_{1}=0.76$ & \multirow{2}{*}{$\mathrm{T}_{1.2}=0.63$} \\
\hline 4-A & 249 & 498 & $\mathrm{~T}_{2}=0.50$ & \\
\hline 4-B & 2289 & 4484 & $\mathrm{~T}_{1}=0.51$ & \multirow{2}{*}{$\mathrm{T}_{1.2}=0.58$} \\
\hline 4-B & 2289 & 3567 & $\mathrm{~T}_{2}=0.64$ & \\
\hline $4-C$ & 1676 & 7039 & $\mathrm{~T}_{1}=0.24$ & \multirow{2}{*}{$\mathrm{T}_{1.2}=0.30$} \\
\hline 4-C & 1957 & 5527 & $\mathrm{~T}_{2}=0.35$ & \\
\hline 5-A & 2824 & 8641 & $\mathrm{~T}_{1}=0.33$ & \multirow{2}{*}{$\mathrm{T}_{1.2}=0.42$} \\
\hline 5-A & 1492 & 2981 & $\mathrm{~T}_{2}=0.50$ & \\
\hline 5-B & 2629 & 6015 & $\mathrm{~T}_{1}=0.44$ & \multirow{2}{*}{$\mathrm{T}_{1,2}=0.53$} \\
\hline 5-B & 3087 & 5065 & $\mathrm{~T}_{2}=0.61$ & \\
\hline $5-C$ & 2783 & 10,379 & $\mathrm{~T}_{1}=0.27$ & \multirow{2}{*}{$\mathrm{T}_{1.2}=0.37$} \\
\hline $5-C$ & 2789 & 5942 & $\mathrm{~T}_{2}=0.47$ & \\
\hline 6 & 2730 & 6019 & $\mathrm{~T}_{1}=0.45$ & \multirow{2}{*}{$\mathrm{T}_{1.2}=0.53$} \\
\hline 6 & 2631 & 4372 & $\mathrm{~T}_{2}=0.60$ & \\
\hline 7 & 463 & 3251 & $\mathrm{~T}_{1}=0.14$ & \multirow{2}{*}{$\mathrm{T}_{1.2}=0.34$} \\
\hline 7 & 529 & 972 & $\mathrm{~T}_{2}=0.54$ & \\
\hline 8 & 424 & 3632 & $\mathrm{~T}_{1}=0.12$ & \multirow{2}{*}{$\mathrm{T}_{1.2}=0.16$} \\
\hline 8 & 518 & 2629 & $\mathrm{~T}_{2}=0.20$ & \\
\hline 9-A & 217 & 492 & $\mathrm{~T}_{1}=0.44$ & \multirow{2}{*}{$\mathrm{T}_{1.2}=0.35$} \\
\hline 9-A & 415 & 1588 & $\mathrm{~T}_{2}=0.26$ & \\
\hline 9-B & 477 & 683 & $\mathrm{~T}_{1}=0.70$ & \multirow{2}{*}{$\mathrm{T}_{1.2}=0.82$} \\
\hline 9-B & 586 & 621 & $\mathrm{~T}_{2}=0.94$ & \\
\hline 9-C & 927 & 1359 & $\mathrm{~T}_{1}=0.68$ & \multirow{2}{*}{$\mathrm{T}_{1.2}=0.43$} \\
\hline $9-C$ & 202 & 1124 & $\mathrm{~T}_{2}=0.18$ & \\
\hline
\end{tabular}


basin has been evaluated by factor of latitudinal topography asymmetry that indicates there is tilting in the most parts and $\mathrm{T}$ has been changed from $16 \%$ for basin $8 \%$ to $82 \%$ for sub-basin $9-\mathrm{B}$. $\mathrm{T}$ is minimum in the lower latitude and it is maximum in the northern latitudes of $28^{\circ} 24^{\prime}$ to $28^{\circ} 40^{\prime}$ where contained the sub basin 9-B. it indicates there is latitudinal topography asymmetry in this area. $\mathrm{T}$ has been increased in the high latitudes in the sub-basins $4-\mathrm{A}$ and $4-\mathrm{B}\left(28^{\circ} 36^{\prime}\right.$ to $29^{\circ} 01^{\prime}$ and $28^{\circ} 38^{\prime}$ to $\left.28^{\circ} 55^{\prime}\right)$ that indicates $\mathrm{T}$ has been increased in the higher latitudes and there is latitudinal topography asymmetry in both sub-basins. Increasing $T$ is related to Saravan Fault and its branches and other active tectonic parameters in the area (Figure 6).

Asymmetry is very high in these areas and the sub-basin 4-A is the most of all. But there is the most symmetry in the sub-basin 1-C. Amounts of Af confirm amount of T exactly (Figure 7).

In this part, active tectonic indices have cause to severe tilting of the drainage basin and increasing amount of T. Supposing that slop of bedrock has affected on moving flow channel insignificantly, direction of flowing the river indicates the tilting in this direction. Values of $\mathrm{T}$ illustrates that preferred moving of flow is vertical on drainage basin axis. This analysis is very proper branched drainage basins because it can study on the branched valleys as the same as the main valley to evaluate values more than $\mathrm{T}$.

\subsection{Sinuosity of the Main Front}

Sinuosity of main front is an index to reflex balance between erosion force (making sinuosity structure) and tectonics (making direct line on the main front). It defines as following:

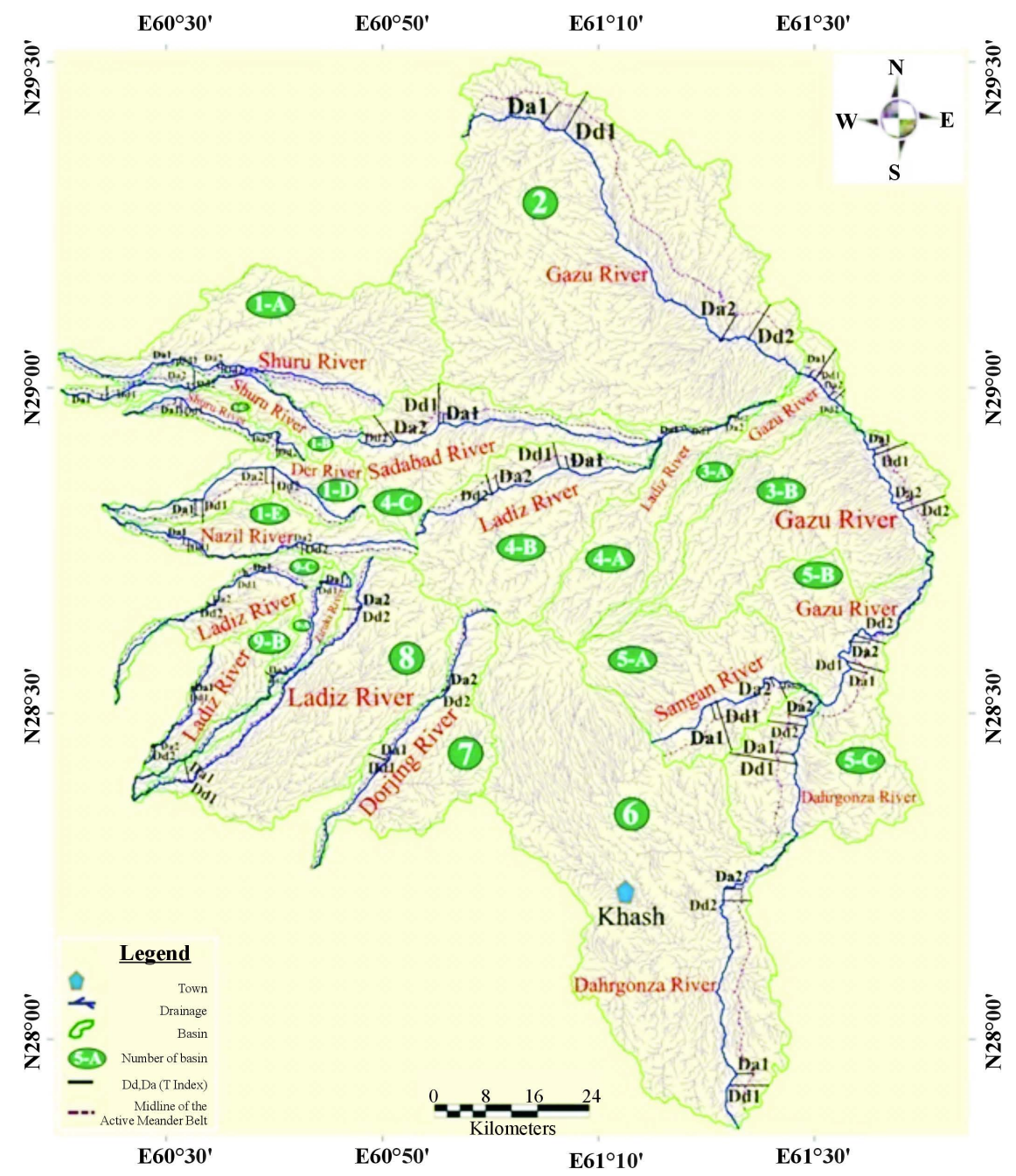

Figure 6. Positions of the areas concluded with T. 


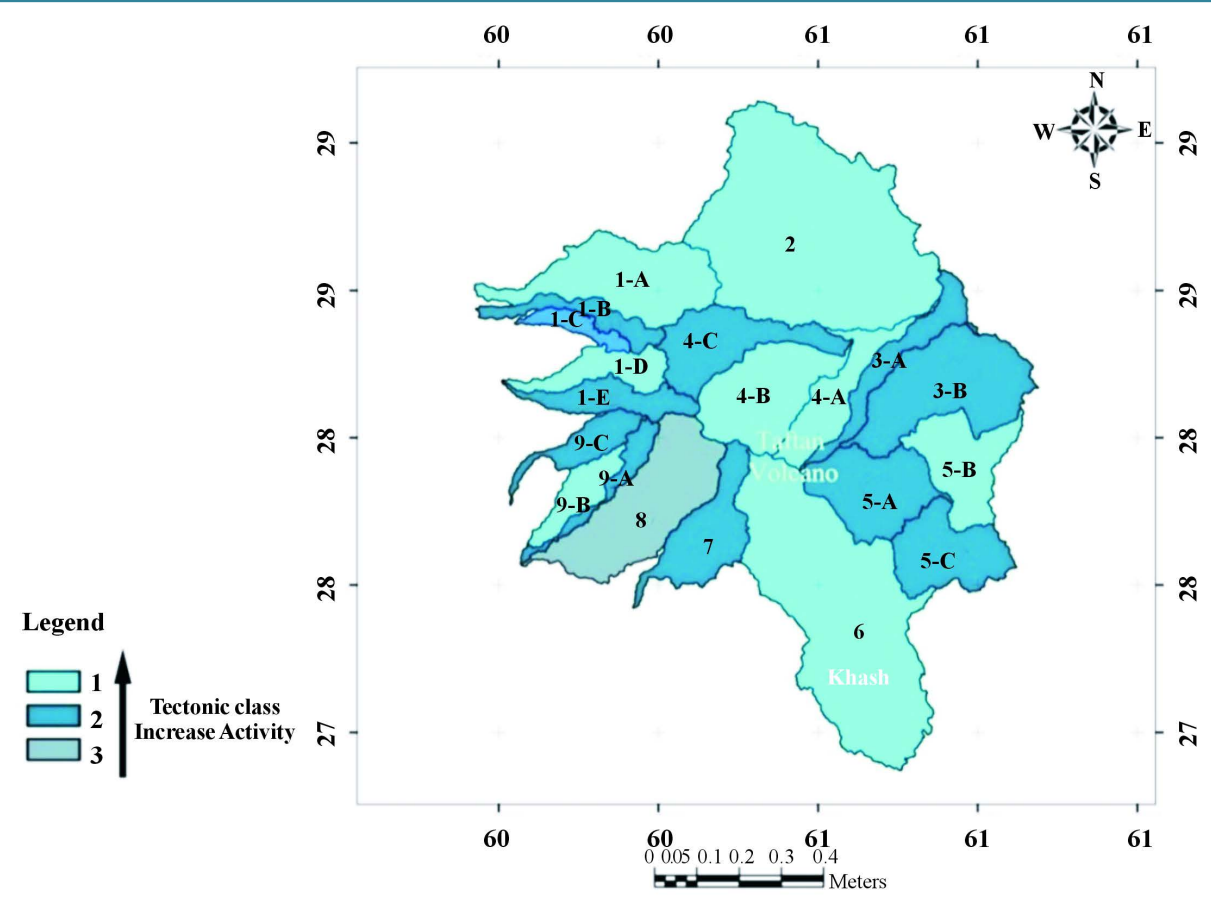

Figure 7. Positions of the basins and categorizing to three groups based on T.

(3)-Sinuosity of the Main Front (Smf): Smf = Lmf/Ls.

The main fronts are related to the active tectonic and direct uplifts and the values of their Smf are low.

Evaluation of average values of Smf (Table 3) for points of 1 - 83 will be changed from 1.02 to 3.26. All available main fronts are active except points of 2, 49, 52, 75, 67 and 78. Except points of 3, 10, 14, 15, 17, 19, $20,21,26,28,37,38,39,49,51,52,53,54,59,62,67,72,74,75,77,78,79,80$ and 82, other point (54 points) are in the similar tectonic class because the values of Smf are less than 1.5 (Figure 8 \& Figure 9). It is found that part 63 is the most active of all. As parts of 68, 69, 70 where related to Saravan Main Front Fault indicate maximum relative active tectonic level and they are in the similar class and they have progressed from north to the south. These parts will be decreased toward the south and it indicates that tectonic action has been increased in point 68. Tectonic action increases from northwest to southeast and it is NW-SE and it decreases from the northwest to the southeast that it indicates there is tectonic action on the south (Figure 10).

If uplift rate is decreased or stopped, erosion process will cause to scarp the main front and Smf will be increased. The values of Smf are depended on the images and the small topographic maps evaluate sinuosity of the main front approximately. Big maps and air pictures that show the main frons are better to compute Smf.

\section{Conclusions}

Regarding morphometric quantitative and qualitative indices and other active tectonic indices and desert studies, it concluded that:

The studied area is divided into nine big basins, totally four basins, 2, 6, 7, 8, 16 and sixteen sub-basins 1-A, 1-B, 1-C, 1-D, 1-E, 3-A, 3-B, 4-A, 4-B, 4-C, 5-A, 5-B, 9-A, 9-B and 9-C .

Smf illustrates that the southeast of the area has more relative active tectonic level than other areas, as a result from uplift and the main faults of main front such as Saravan Fault. The most active area in altitude of $1400 \mathrm{~m}$ is one of the minor branches of Saravan Fault that located on the east of this area. This area is ready to earthquake.

On the basis of $\mathrm{T}$, it found that all basins and sub-basins are affected by tilting. The values of $\mathrm{T}$ indicate that preferred movement of rivers is vertical on drainage axis that is a horizontal tilting. Increasing $\mathrm{T}$ in the basins in high longitudes especially in the sub-basins of $4-\mathrm{A}\left(28^{\circ} 36^{\prime}\right.$ to $\left.29^{\circ} 01^{\prime}\right)$, $4-\mathrm{B}\left(28^{\circ} 38^{\prime}\right.$ to $\left.29^{\circ} 55^{\prime}\right)$ indicates Asymmetry of Latitudinal Topography in both basins. This increasing of $\mathrm{T}$ is related to many faults of minor branches of Saravan Fault and other active tectonic parameters. There is the most asymmetry in theses basins. According to asymmetry and symmetry latitudinal topographic factors, the most asymmetry is related to sub-basin of 4-A. but 
Table 3. The values of Smf for the measured points.

\begin{tabular}{|c|c|c|c|c|}
\hline Basin & Segment & Lmf (m) & Ls (m) & Smf (m) \\
\hline Basin 2 & $1(1550 \mathrm{~m})$ & 6862 & 5598 & 1.23 \\
\hline Basin 2 & $2(1450 \mathrm{~m})$ & 3643 & 1651 & 2.21 \\
\hline Basin 2 & $3(1400 \mathrm{~m})$ & 8269 & 5114 & 1.62 \\
\hline Basin 2 & $4(1500 \mathrm{~m})$ & 1438 & 1233 & 1.17 \\
\hline Basin 2 & $5(1550 \mathrm{~m})$ & 2899 & 2692 & 1.08 \\
\hline Basin 2 & $6(1350 \mathrm{~m})$ & 4961 & 3911 & 1.27 \\
\hline Basin 2 & $7(1450 \mathrm{~m})$ & 2705 & 2484 & 1.09 \\
\hline Basin 2 & $8(1500 \mathrm{~m})$ & 2737 & 2414 & 1.13 \\
\hline Basin 2 & $9(1200 \mathrm{~m})$ & 3763 & 3469 & 1.08 \\
\hline Basin 2 & $10(1250 \mathrm{~m})$ & 10,594 & 5377 & 1.97 \\
\hline Basin 2 & $11(1300 \mathrm{~m})$ & 5495 & 3743 & 1.47 \\
\hline Basin 2 & $12(1400 \mathrm{~m})$ & 4112 & 3035 & 1.35 \\
\hline Basin 2 & $13(1200 \mathrm{~m})$ & 827 & 695 & 1.19 \\
\hline Basin 2 & $14(1500 \mathrm{~m})$ & 1321 & 764 & 1.73 \\
\hline Basin 2 & $15(1450 \mathrm{~m})$ & 3861 & 2511 & 1.54 \\
\hline Basin 2 & $1(1550 \mathrm{~m})$ & 6862 & 5598 & 1.23 \\
\hline Basin 2 & $2(1450 \mathrm{~m})$ & 3643 & 1651 & 2.21 \\
\hline Basin 2 & $3(1400$ m) & 8269 & 5114 & 1.62 \\
\hline Basin 2 & $4(1500 \mathrm{~m})$ & 1438 & 1233 & 1.17 \\
\hline Basin 2 & $5(1550 \mathrm{~m})$ & 2899 & 2692 & 1.08 \\
\hline Basin 2 & $6(1350 \mathrm{~m})$ & 4961 & 3911 & 1.27 \\
\hline Basin 3-B & $56(1250 \mathrm{~m})$ & 6892 & 5028 & 1.37 \\
\hline Basin 3-B & $57(1200 \mathrm{~m})$ & 4231 & 3962 & 1.07 \\
\hline Basin 3-B & $58(1150 \mathrm{~m})$ & 442 & 391 & 1.13 \\
\hline Basin 3-B & $59(1100 \mathrm{~m})$ & 6118 & 3462 & 1.77 \\
\hline Basin 3-B & $60(1050 \mathrm{~m})$ & 1924 & 1702 & 1.13 \\
\hline Basin 5-B & $61(1350 \mathrm{~m})$ & 2793 & 2241 & 1.25 \\
\hline Basin 5-B & $62(1350 \mathrm{~m})$ & 4521 & 2506 & 1.8 \\
\hline Basin 3-B & $63(1400 \mathrm{~m})$ & 809 & 790 & 1.02 \\
\hline Basin 3-B & $64(1350 \mathrm{~m})$ & 4105 & 2880 & 1.43 \\
\hline Basin 5-B & 65 (950 m) & 4693 & 3805 & 1.23 \\
\hline Basin 5-B & $66(900 \mathrm{~m})$ & 3684 & 2502 & 1.47 \\
\hline Basin 5-B & $67(1100 \mathrm{~m})$ & 3925 & 1877 & 2.09 \\
\hline Basin 5-C & $68(1350 \mathrm{~m})$ & 3636 & 3045 & 1.19 \\
\hline Basin 5-C & $69(1300 \mathrm{~m})$ & 6064 & 4133 & 1.47 \\
\hline Basin 5-C & $70(1250 \mathrm{~m})$ & 8375 & 5901 & 1.42 \\
\hline Basin 6 & $71(1400 \mathrm{~m})$ & 5728 & 4708 & 1.22 \\
\hline Basin 6 & $72(1550 \mathrm{~m})$ & 2861 & 1806 & 1.58 \\
\hline Basin 6 & $73(1600 \mathrm{~m})$ & 2486 & 2006 & 1.243 \\
\hline Basin 7 & $74(1600 \mathrm{~m})$ & 10,681 & 6475 & 1.65 \\
\hline Basin 7 & 75 (1550 m) & 10,695 & 3285 & 3.26 \\
\hline Basin 8 & $76(1650 \mathrm{~m})$ & 2783 & 1879 & 1.48 \\
\hline Basin 8 & 77 (1700 m) & 5802 & 3306 & 1.75 \\
\hline Basin 8 & $78(1800$ m) & 6652 & 3105 & 2.14 \\
\hline Basin 9-A, 9-B & 79 (1650 m) & 9561 & 5452 & 1.75 \\
\hline Basin 9-B & $80(1600 \mathrm{~m})$ & 8920 & 5245 & 1.7 \\
\hline
\end{tabular}




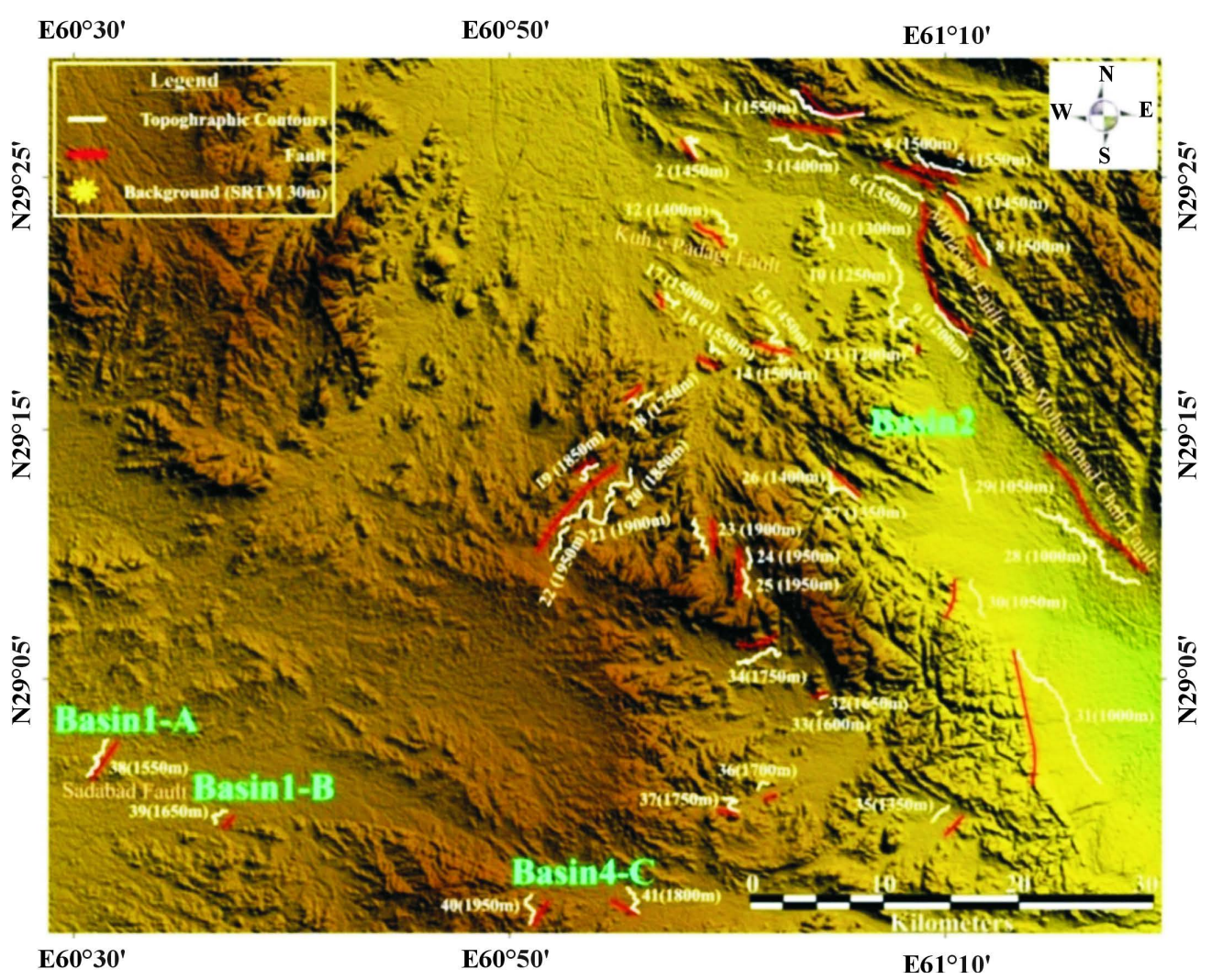

Figure 8. Positions of Points 1-83 concluded with Smf.

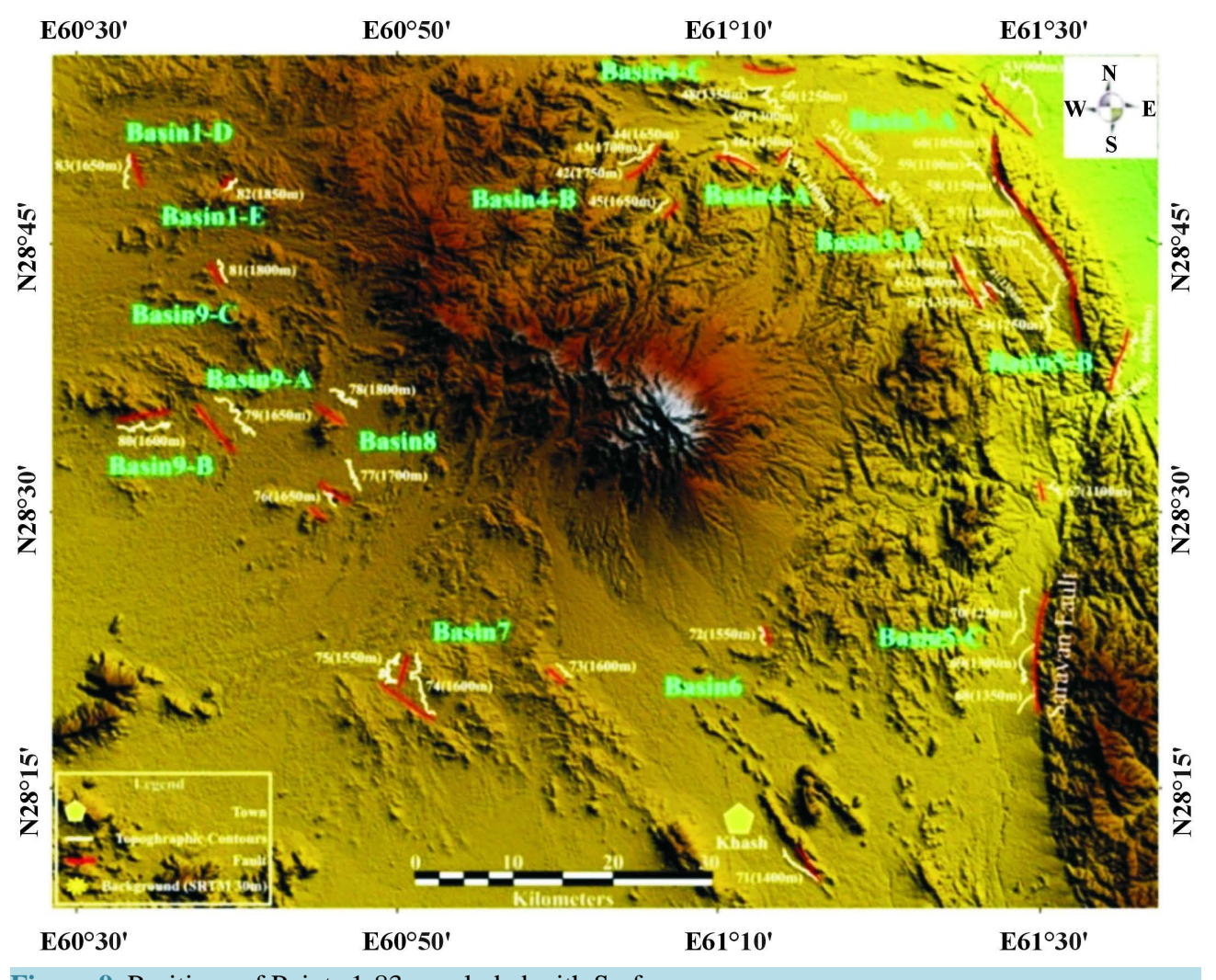

Figure 9. Positions of Points 1-83 concluded with Smf. 


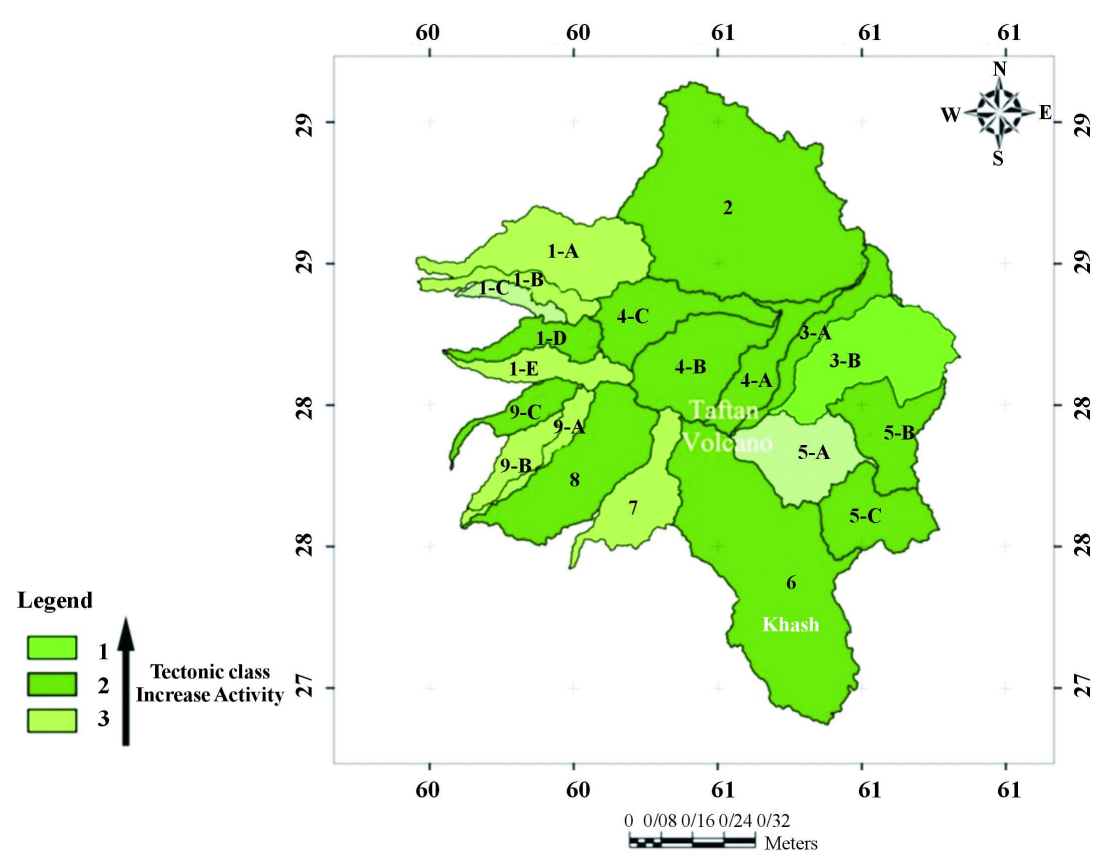

Figure 10. Positions of the basins and categorizing to three groups based on Smf.

the most symmetry is related to sub-basin of 1-C. The values of Af confirm the values of T very well.

\section{References}

[1] Aghanabati, A. (2004) Iran Geology. State Department of Geology Organization, Iran.

[2] Alavi, M. (1991) Sedimentary and Structural Characteristics of the Paleo-Tethys Remnants in Northeastern Iran. Geology Society of American, 103, 983. http://dx.doi.org/10.1130/0016-7606(1991)103<0983:sascot>2.3.c0;2

[3] Eftekharnezhad, J. (1980) Separating Different Parts of Iran in Vies of Constructional Position Related too Sedimentary Basins. Petrol Association Publication No: 82.

[4] Berbarian, M. and King, G.C.P. (1981) Towards a Paleo Geography and Tectonic Evelution of Iran. Report No. 52, Geological Survey of Iran.

[5] Reyer, D. and Mohafez, S.A. (1972) First Contribution of the NIOC-ERAP Agreements to the Knowledge of Iranian Geology. Edition Techniqs, Paris, 58 p.

[6] Tirrul, R., Bell, I.R., Griffis, R.J. and Camp, V.E. (1983) The Sistan Suture Zone of Eastern Iran. Geological Society of America Bulletin, 94, 134. http://dx.doi.org/10.1130/0016-7606(1983)94<134:TSSZOE >2.0.CO;2

[7] Arian, M. and Pourkermani, M. (2004) Tectonic Elements of South Flank in the East-Central Alborz Mountain. Journal of Sciences, Techer training University, 4, 359-368.

[8] Berberian, M. (1976) Quaternary Faults in Iran in: Contribution to the Seismotectonics of Iran (Part II). Geology Survey of Iran, Rep No: 39.

[9] Hare, P.H. and Gardner, T.W.M. (1985) Geomorphic Indicators of Vertical Neotectonism along Converging Plate Margins, Nicoya Peninsula, Costa Rica. In: Morisawa, M. and Hach, J.T., Eds., Tectonic Geomorphology, Allen and Unwin, Boston, 75-104.

[10] Keller, E.A. and Pinter, N. (2002) Active Tectonics, Earthquakes, Uplift and Landscape. Prentice Hall, New Jersey.

[11] Poorkermani, M. and Solgi, A. (2009) Morphtectonic. Islamic Azad University Publication, Tehran. 